\title{
КЛИНИЧЕСКИЙ СЛУЧАЙ ГИПОИНСУЛИНЕМИЧЕСКОЙ ГИПОГЛИКЕМИИ ВСЛЕДСТВИЕ МУТАЦИИ ГЕНА АКТ2
}

\author{
1,2Чагай Н.Б., 'Данникова Ю.А., 'Левандовская Н.П.
}

\begin{abstract}
'АНМО «Ставропольский краевой клинический консультативно-диагностический центр», Ставрополь 2ФГБОУ ВО «Ставропольский государственный медицинский университет» Минздрава России, Ставрополь
\end{abstract}

Гипогликемическое состояние диагностируется у детей при снижении глюкозы ниже 2,6-3,3 ммоль/л в разные периоды жизни. Исключив гипогликемии транзиторные, вследствие тяжелой соматической патологии, отравления, следует дифференцировать гипогликемии после приема пищи и на фоне голодания. Отсутствие кетоновых лет опровергает гипогликемии при дефиците субстрата окисления, нарушениях гликогенолиза, глюконеогенеза, окислении жирных кислот.

Пациентка К., 2018 г.р. с задержкой моторного развития после дебюта судорожного синдрома в возрасте 5,5 месяца. В возрасте 7,5 месяца вес 9,9 кг, рост 68 см, окружность головы 44,5 см, большой родничок 2,5×2,0 см. Складки «избыточной» кожи на шее, конечностях, узкое лицо, пухлые щеки, седловидная переносица, вздернутый кончик носа, кожная привеска на мочке левого уха. Диффузная мышечная гипотония.

Гликемия натощак от 1,42 до 3,1 ммоль/л, через 2 ч после еды до 4,0 ммоль/л, гликированный гемоглобин 4,7\%, С-пептид натощак 0,14 нг/мл, через 2 ч после еды 0,275 нг/мл (N 0,9-7,1); инсулин натощак 0,11 мМЕ/мл, моча на кетоны неоднократно отрицательно.

Билирубин общий 19 мкмоль/л, креатинфосфокиназа (КФК) 120 Ед/л, КФК МВ 34 Ед/л, АЛТ 30 Ед/л, натрий 140 ммоль/л, калий 5,4 ммоль/л, ионизированный кальций 1,32 ммоль/л, фосфор 1,86 ммоль/л, магний 0,84 ммоль/л (N 0,77-1,03), креатинин 85 мкмоль/л, кортизол 287 нмоль/л, инсулиноподобный фактор роста-1 (ИФР-1) 37,5 нг/мл (N 18,2-172), интактный паратгормон 32,7 пг/мл (N 12-75),

Компьютерная томография головного мозга: признаки гипоксического поражения мозга в стадии энцефаломаляции и постэнцефалитической дегенерации.

ДНК-панель «Клинический экзом»: варианты нуклеотидной последовательности в 18 экзоне гена ARIDIA в гетерозиготном состоянии, приводящей к замене аминокислоты в 1406 позиции белка (характерны для синдрома Коффина-Сириса 2, доминантный тип наследования). Выявлены варианты нуклеотидной последовательности в гене CACNA IH в гетерозиготном состоянии («Предрасположенность к идиопатической генерализованной эпилепсии 6») и в гене AKT2 в 3 экзоне с. G49A в гетерозиготном состоянии (характерен для «Гиперинсулинемической гипогликемии с гемигипертрофией», аутосомно-доминантный тип наследования). ДНК-панель «Гипогликемическая» - подтвержден дефект гена AKT2.

B 2004 г. Hussain K. et al. представлено наблюдение мальчика с гемигипертрофией, тяжелой персистирующей гипокетотической, гипофатацидемической, гипоинсулинемической гипогликемией, угнетением контррегуляторных реакций, вероятно, по причине лиганд-независимой активации путей передачи сигнала инсулина и/или ИФР-1.

Ген AKT2 кодирует синтез одноименной протеинкиназы Akt2 и участвует в активации инсулин-опосредованной транслокации GLUT4, транспортировке глюкозы и ее поглощении скелетными мышцами, а также накоплении триглицеридов в печени. Мутация АКТ2, вероятно, определяет постоянную активацию глюкозного транспорта, имитируя инсулин-индуцированные сигналы, и проявляется гипоинсулинемической гипогликемией.

На основании данных клинической картины, анамнеза, лабораторно-инструментальных исследований установлен диагноз: основной - синдром гипоинсулинемической гипогликемии с гемигипертрофией, аутосомно-доминантный тип наследования; сопутствующий - синдром Коффина-Сириса, аутосомнодоминантный тип наследования. 